\begin{tabular}{|c|c|}
\hline Title & Determination of undried rough rice constituent content using near-infrared transmission spectroscopy \\
\hline Author(s) & Kawamura, S.; Natsuga, M.; Itoh, K. \\
\hline Citation & $\begin{array}{l}\text { Transactions of the A SA E, 42(3), } 813-818 \\
\text { https://doi.org/10.13031/2013.13246 }\end{array}$ \\
\hline Issue Date & 1999 \\
\hline Doc URL & http:/hdl.handle.net/2115//1225 \\
\hline Rights & (-1999 A merican Society of A gricultural Engineers 0001-2351/99/4203-813 \\
\hline Type & article \\
\hline File Information & Ka1999-2 Rough Rice NIRT Published A SA E.pdf \\
\hline
\end{tabular}

Instructions for use 


\title{
DETERMINATION OF UNDRIED ROUGH Rice CONSTITUENT CONTENT USING NEAR-INFRARED TRANSMISSION SPECTROSCOPY
}

\author{
S. Kawamura, M. Natsuga, K. Itoh
}

\begin{abstract}
Near-infrared transmission (NIRT) spectroscopy was used in an attempt to predict moisture content, protein content and amylose content from undried whole-grain rough rice spectra. One hundred-fifty undried rough rice samples were collected. Using partial least squares calibration models obtained from undried whole-grain rough rice spectra, the coefficient of determination $\left(r^{2}\right)$ and the standard error of prediction (SEP) of the validation set were $r^{2}=0.96$ and $S E P=0.70$ for rough rice moisture content, $r^{2}=0.70$ and $S E P=0.24$ for brown rice protein content, $r^{2}=0.76$ and $S E P=0.22$ for milled rice protein content, and $r^{2}=0.00$ and $S E P=0.27$ for milled rice amylose content. The results of the validation indicated that NIRT could be used to determine moisture content and protein content. Thus, NIRT technology may be used to classify undried rough rice into qualitative groups such as high protein content rice and low protein content rice upon arrival at a rice-drying facility after harvesting.
\end{abstract}

Keywords. Near-infrared transmission spectroscopy, Undried rough rice, Moisture, Protein, Amylose.

$\mathrm{T}$ he first commercially produced near-infrared (NIR) spectroscopy instrument was a NIR reflectance (NIRR) spectrometer that was designed for analysis of dried ground grain; for example, to determine the protein content in wheat (Osborne, 1995). Since then, applications of NIRR to grain analysis have been at the forefront of NIR technology. Near-infrared transmission (NIRT) spectroscopy and a calibration modeling method of partial least squares (PLS) have recently been introduced. NIR technology is widely used for assessing grain quality; however, a method for assessing the quality of undried whole grain by NIR technology has not yet been established.

Milled rice (i.e., rice from which the hull, bran layer and embryo have been removed) is usually used for cooking. The major chemical constituents of milled rice are moisture, protein, and starch (amylose and amylopectin). The protein content of milled rice is a very important quality item, especially in East Asian countries, where people eat short-grain, non-waxy rice.

Ishima et al. (1974), Yanase et al. (1984), and Shibuya (1990) reported that the protein content of rice is important because:

- Protein inhibits water absorption and starch swelling when milled rice is cooked.

- Protein greatly affects the texture of cooked rice.

- Rice with a high protein content is less sticky when cooked.

Article was submitted for publication in June 1998; reviewed and approved for publication by the Information \& Electrical Technologies Division of ASAE in February 1999. Presented as ASAE Paper No. 973026.

The authors are Shuso Kawamura, ASAE Member Engineer, Associate Professor, Motoyasu Natsuga, ASAE Member Engineer, Researcher, and Kazuhiko Itoh, Professor, School of Agricultural Science, Hokkaido University, Sapporo, Japan. Corresponding author: Dr. Shuso Kawamura, Hokkaido University, School of Agricultural Science, Agricultural Process Engineering Laboratory, Sapporo 060-8589, Japan.e-mail: shuso@bpe.agr.hokudai.ac.jp.
- East Asian people prefer sticky cooked rice.

- Rice with low protein content is accordingly evaluated as being more palatable in East Asian countries.

After harvesting, undried rough rice is transported to a drying facility. Upon arrival at the drying facility, the moisture content of the rough rice is checked using an electric resistance grain moisture meter or a dielectric grain moisture meter. Recently, there has been a need in ricedrying facilities for an accurate method to measure not only the moisture content but also the protein content of undried rough rice in order to grade the rice according to quality at the receiving pit.

Recent studies have demonstrated that NIR spectroscopy can be used to measure chemical constituents, texture and taste of rice. Natsuga et al. (1992) reported on the precision and accuracy of NIRR in determining moisture content and protein content of ground brown rice and ground milled rice. Suzuki et al. (1996) discussed factors affecting the accuracy of analysis of protein in ground brown rice using NIRR. Villareal et al. (1994) and Delwiche et al. (1995) reported on analysis of amylose in milled rice using NIRT and NIRR, respectively. Li and Shaw (1997) developed a calibration model to determine the fat acidity of rough rice by NIRR. Chen et al. (1997) developed visible/NIRR calibration models to quantify the surface lipid content of milled rice. Delwiche et al. (1996) measured quality characteristics of whole-grain milled rice by NIRR. Windham et al. (1997) used NIRR analysis of whole-grain milled rice to predict texture quality of the rice when cooked. Kawamura et al. (1991, 1996, 1997) attempted to assess the taste evaluation of rice using NIRR.

It has been difficult to determine undried rough rice constituent content using NIR. Therefore, next step in NIR technology development is to apply the technology to undried whole-grain rough rice. The objectives of this study were to develop NIRT calibration models for determining the constituent content of undried whole-grain 
rough rice and to validate the accuracy of the calibration models.

\section{MATERIALS AND MeTHODS RICE SAMPLES}

A popular Japanese short-grain, non-waxy variety of rice, "Kirara 397", was selected for this study. Figure 1 shows the sample processing procedures, and table 1 shows the number of samples used in this study. A total of 150 samples of undried rough Kirara 397 rice (1500 g/sample) were collected at the receiving pit of a drying facility. Each undried rough rice sample was divided into two parts. One part of the undried rough rice sample was hulled in a huller (model FC1K-MS, Otake, Aichi, Japan) to obtain an undried brown rice sample (600 g/sample), and the other part was dried under constant conditions in a test dryer (model TDR-48C, Satake Engineering, Tokyo, Japan) to obtain a dried rough rice sample (650 g/sample) and then hulled in a huller (model PI-60C, Satake Engineering, Tokyo, Japan) to obtain a brown rice sample ( $500 \mathrm{~g} / \mathrm{sample})$. A portion of the brown rice sample was then milled in a friction mill (model MCM-250, Satake Engineering, Tokyo, Japan) to obtain a milled rice sample (180 g/sample). Each sample processing procedure was done under constant settings and conditions for each sample. The milling procedure, for example, was done by passing the rice through the friction mill four times while adjusting back pressure on the rice in the milling

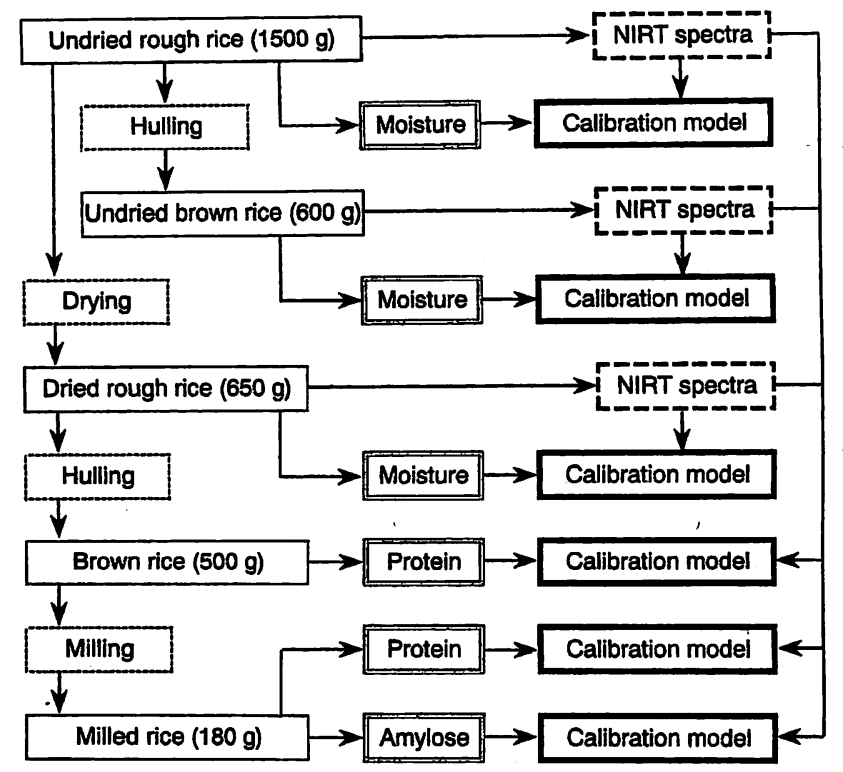

Figure 1-Sample processing procedures and reference, spectroscopic, and chemometric analyses.

\begin{tabular}{|c|c|c|c|c|c|c|}
\hline \multirow[b]{2}{*}{ Sample } & \multirow[b]{2}{*}{$\begin{array}{l}\text { Light Path } \\
\text { Length } \\
\text { (mm) }\end{array}$} & \multirow{2}{*}{$\begin{array}{c}\text { Number of } \\
\text { Samples- } \\
\text { NIRT Spectra } \\
\text { Wave Measured }\end{array}$} & \multicolumn{4}{|c|}{$\begin{array}{l}\text { Number of Samples Used } \\
\text { in Calibration and Validation }\end{array}$} \\
\hline & & & $\begin{array}{l}\text { Moisture } \\
\text { Content }\end{array}$ & $\begin{array}{c}\text { Brown Rice } \\
\text { Protein } \\
\text { Content }\end{array}$ & $\begin{array}{c}\text { Milled Rice } \\
\text { Protein } \\
\text { Content }\end{array}$ & $\begin{array}{c}\text { Milled Rice } \\
\text { Amylose } \\
\text { Content }\end{array}$ \\
\hline $\begin{array}{l}\text { Undried } \\
\text { rough rice }\end{array}$ & $\begin{array}{r}20 \\
\quad 25\end{array}$ & $\begin{array}{l}106 \\
150\end{array}$ & $\begin{array}{r}90 \\
134\end{array}$ & $\begin{array}{l}105 \\
148\end{array}$ & $\begin{array}{l}106 \\
149\end{array}$ & $\begin{array}{l}106 \\
150\end{array}$ \\
\hline $\begin{array}{l}\text { Dried } \\
\text { rough rice }\end{array}$ & $\begin{array}{r}20 \\
e \quad 25\end{array}$ & $\begin{array}{l}150 \\
150\end{array}$ & $\begin{array}{l}150 \\
149\end{array}$ & $\begin{array}{l}150 \\
150\end{array}$ & $\begin{array}{l}150 \\
150\end{array}$ & $\begin{array}{l}150 \\
150\end{array}$ \\
\hline $\begin{array}{l}\text { Undried } \\
\text { brown rice }\end{array}$ & 30 & 150 & 136 & 148 & 148 & 150 \\
\hline
\end{tabular}

chamber to control the milling degree at $90.4 \%( \pm 0.2 \%)$. The milling degree was defined as the weight of milled rice divided by the weight of brown rice.

\section{SPECTROSCOPIC ANALYSES}

A near-infrared transmission (NIRT) spectrometer (model Grainspec-1000J, Foss Electric, Hillerod, Denmark) was used to obtain NIRT spectra of undried rough rice, undried brown rice and dried rough rice (fig. 1) over a wavelength range of 825 to $1075 \mathrm{~nm}$. The spectrometer had three tuning levels and 11 fixed filters, and it could thus scan 33 wavelengths between 825 and $1075 \mathrm{~nm}$. For each sample, 300 to $400 \mathrm{~g}$ of undried rough rice and dried rough rice, and 500 to $600 \mathrm{~g}$ of undried brown rice were poured into the hopper of the spectrometer and loaded automatically into a sample cell. The loading into the sample cell was repeated ten times. The NIR energy that was transmitted through the grain sample was detected by a silicon photocell array, converted into an electrical signal, and processed by a CPU to be transformed to $\log (1 / \mathrm{T})$. One scan for each loading was saved in computer memory. Ten scans were performed, and the data were averaged to obtain an NIRT spectrum for each sample. Figure 2 shows a set of near-infrared transmission spectra of 150 undried rough rice samples.

The grain capacity in the sample cell was adjustable according to the type of grain. This capacity was referred to as the light path length of the cell. After a preliminary test, spectral data for undried rough rice and dried rough rice were then collected with two light path lengths of $20 \mathrm{~mm}$ and $25 \mathrm{~mm}$, and spectral data for undried brown rice were collected with a light path length of $30 \mathrm{~mm}$. The spectral data for 44 undried rough rice samples collected with a light path length of $20 \mathrm{~mm}$ exceeded the sensitivity of the silicon photocell array because of the low density of the sample in the sample cell. Thus, NIRT spectra with a light path length of $20 \mathrm{~mm}$ were obtained from 106 undried rough rice samples (table 1 ).

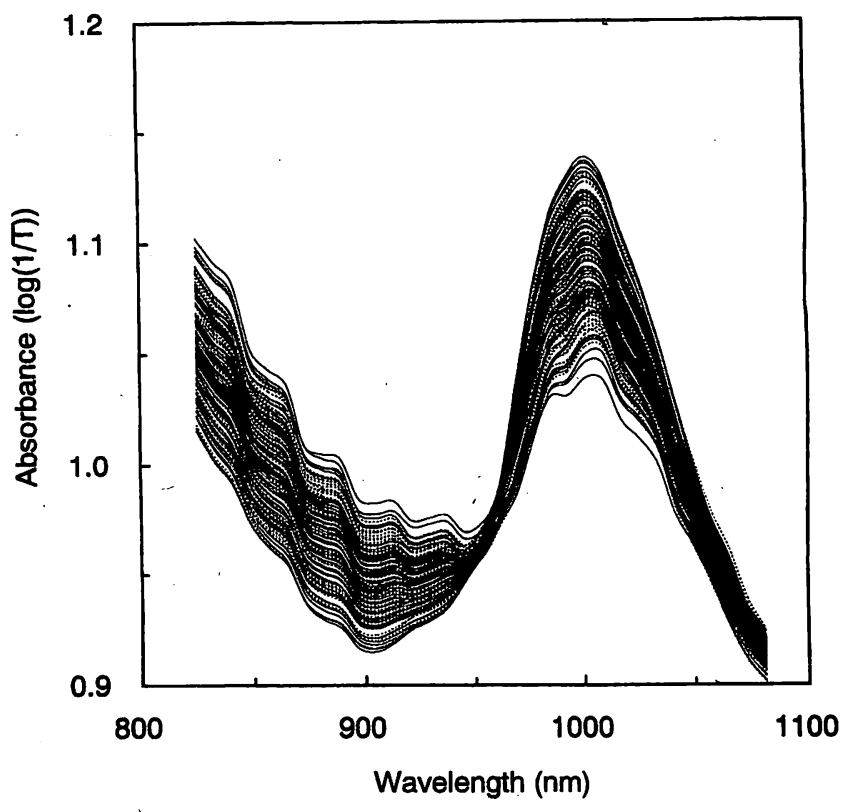

Figure 2-Near-infrared transmission spectra of 150 undried rough rice samples (25-mm light path length). 


\section{REFERENCE ANALYSES}

Moisture contents of the undried rough rice samples, undried brown rice samples and dried rough rice samples (fig. 1) were determined by the official method of the Japan Food Agency (1989). Five grams of ground rice were placed in a forced-air oven at $105^{\circ} \mathrm{C}$ for $5 \mathrm{~h}$, and moisture was computed on a wet basis. Protein contents of brown rice and milled rice (fig. 1) were determined by the Kjeldahl method $(\mathrm{N} \times 5.95)$ and calculated on a dry basis. Amylose content (apparent amylose content) of milled rice was measured with an autoanalyzer, following the protocol of Williams et al. (1958) with modifications by Inatsu (1988). Each reference analysis was repeated twice for each sample.

Table 2 shows the precision of the reference analysis. When the difference between two computations of moisture content was more than $1 \%$, the data were not used in calibration and validation sets for moisture content. The number of undried rough rice and undried brown rice samples in which the moisture content was measured consequently decreased to 134 and 136 (table 2). Despite the exclusion of the excessive moisture difference samples, the values of the standard deviation of the difference (SDD) in measured moisture content of undried rough rice $(0.32)$ and undried brown rice $(0.29)$ were larger than that of dried rough rice $(0.21)$. The SDD data indicated that high-moisture rice had a large moisture deviation.

\section{Chemometric Analyses}

Figure 1 shows the procedure for chemometric analysis. The calibration models used to estimate the moisture content of undried rough rice, undried brown rice and dried rough rice were developed from undried rough rice NIRT spectra, undried brow rice NIRT spectra and dried rough rice NIRT spectra, respectively. The models used to estimate the protein content of brown rice and milled rice were developed from undried rough rice NIRT spectra, undried brown rice NIRT spectra, and dried rough rice NIRT spectra. The models used to estimate the amylose content of milled rice were developed from undried rough rice NIRT spectra, undried brown rice NIRT spectra, and dried rough rice NIRT spectra.

Spectral data analysis software (Data Tracker, Foss Electric, Hillerod, Denmark) was used for the chemometric analysis. The samples were randomly divided into two groups: a calibration set containing two-thirds of the samples and a validation set containing the remainder (one-third) of the samples. The method of partial least squares (PLS) was used to develop calibration models from the original spectra sets [as $\log (1 / \mathrm{T})$ as in fig. 2] of undried

Table 2. Precision of reference analysis

\begin{tabular}{llccc}
\hline $\begin{array}{l}\text { Reference } \\
\text { Analysis }\end{array}$ & Sample & $\mathrm{n}^{*}$ & $\begin{array}{c}\text { Range } \\
(\%)\end{array}$ & $\begin{array}{c}\text { SDD } \dagger \\
(\%)\end{array}$ \\
\hline Moisture content & Undried rough rice & 134 & $15.4-34.8$ & 0.32 \\
& Dried rough rice & 150 & $12.7-17.1$ & 0.21 \\
& . Undried brown rice & 136 & $15.9-32.1$ & 0.29 \\
\hline Protein content & Brown rice & 150 & $7.3-9.4$ & 0.07 \\
& Milled rice & 150 & $6.7-8.9$ & 0.05 \\
\hline Amylose content & Milled rice & 150 & $20.6-21.9$ & 0.18 \\
\hline
\end{tabular}

* Number of samples.

$\dagger$ Standard deviation of difference.

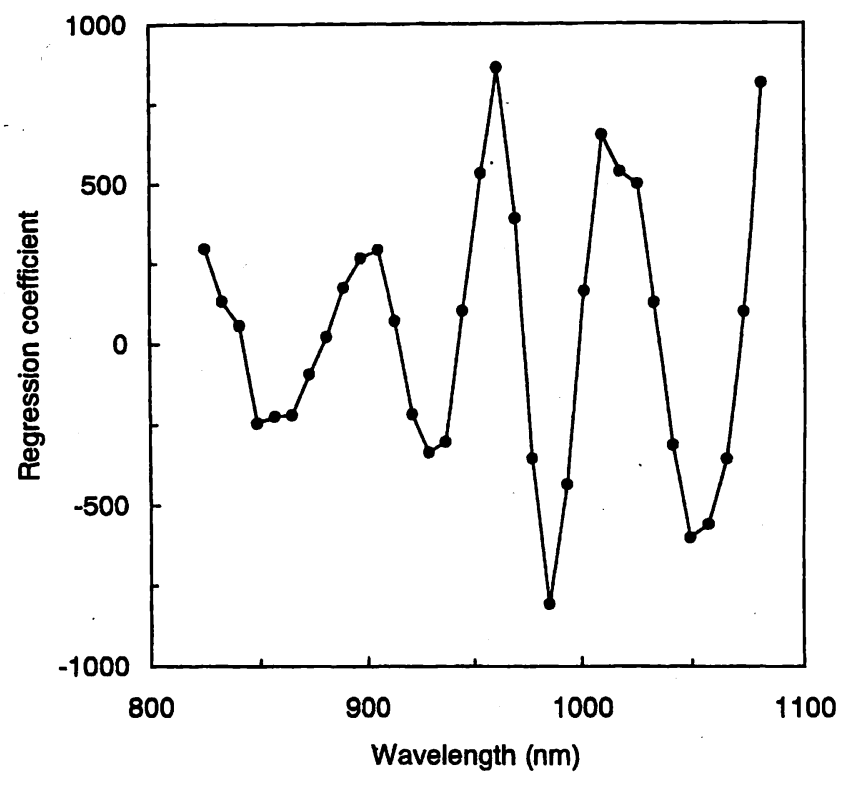

Figure 3-Regression coefficients for calculating the moisture content of undried rough rice (25-mm light path length).

rough rice and dried rough rice collected with two light path lengths of $20 \mathrm{~mm}$ and $25 \mathrm{~mm}$. Pretreatment such as smoothing or derivatives was not performed on the original spectra. As the number of PLS factors ( $\mathrm{nF}$ ) increased in the PLS regression analysis, the standard error of calibration (SEC) usually decreased. The number of factors was selected when SEC reached a minimum. Figure 3 shows a set of regression coefficients calculating the moisture content of undried rough rice. In the PLS regression, all of the wavelengths were used for prediction.

Outliers were sometimes omitted at calibration and validation. The number of samples used in calibration and validation sets for moisture content of undried rough rice with a light path length of $20 \mathrm{~mm}$, for example, was 90 because 44 samples with an excessive NIRT signal were excluded, and 16 samples with an extreme moisture difference of duplicates from the 150 samples (table 1) were excluded.

\section{RESUlTS AND Discussion MOISTURE ConTENT}

The results of PLS calibration modeling and validation statistics for moisture content are summarized in table 3 . For each sample and each light path length, the coefficient

Table 3. Calibration and validation statistics for moisture content

\begin{tabular}{|c|c|c|c|c|c|c|c|c|c|c|c|}
\hline \multirow[b]{2}{*}{ Sample } & \multirow{2}{*}{$\begin{array}{l}\text { Light } \\
\text { Path } \\
\text { Length } \\
(\mathrm{mm})\end{array}$} & \multirow{2}{*}{ th $n^{*}$} & \multicolumn{4}{|c|}{ Calibration Model } & \multicolumn{5}{|c|}{ Validation } \\
\hline & & & $\begin{array}{c}\text { Range } \\
(\%)\end{array}$ & $\mathrm{nF} \dagger$ & $r^{2} \ddagger$ & $\begin{array}{c}\text { SEC } \\
(\%)\end{array}$ & $\mathrm{n}$ & $\begin{array}{c}\text { Range } \\
(\%)\end{array}$ & $\mathrm{r}^{2}$ & $\begin{array}{l}\text { SEPII } \\
(\%)\end{array}$ & $\begin{array}{l}\text { Bias } \\
(\%)\end{array}$ \\
\hline $\begin{array}{l}\text { Undried } \\
\text { rough rice }\end{array}$ & $\begin{array}{r}20 \\
\quad 25 \\
\end{array}$ & $\begin{array}{l}59 \\
90 \\
\end{array}$ & $\begin{array}{l}20.2-32.6 \\
15.4-34.8 \\
\end{array}$ & $\begin{array}{l}7 \\
7 \\
\end{array}$ & $\begin{array}{l}0.95 \\
0.97 \\
\end{array}$ & $\begin{array}{l}0.72 \\
0.70 \\
\end{array}$ & $\begin{array}{l}31 \\
44\end{array}$ & $\begin{array}{l}21.3-32.6 \\
15.5-33.2\end{array}$ & $\begin{array}{l}0.96 \\
0.96 \\
\end{array}$ & $\begin{array}{l}0.64 \\
0.70 \\
\end{array}$ & $\begin{array}{l}-0.31 \\
-0.04\end{array}$ \\
\hline $\begin{array}{l}\text { Dried } \\
\text { rough rice }\end{array}$ & $\begin{array}{ll}201 \\
& 25\end{array}$ & $\begin{array}{r}100 \\
99\end{array}$ & $\begin{array}{l}12.7-17.1 \\
12.7-16.7\end{array}$ & $\begin{array}{l}7 \\
7\end{array}$ & $\begin{array}{l}0.91 \\
0.92\end{array}$ & $\begin{array}{l}0.26 \\
0.24\end{array}$ & $\begin{array}{l}50 \\
50\end{array}$ & $\begin{array}{l}12.7-16.7 \\
12.7-17.1\end{array}$ & $\begin{array}{l}0.92 \\
0.90\end{array}$ & $\begin{array}{l}0.24 \\
0.28\end{array}$ & $\begin{array}{l}-0.03 \\
-0.03\end{array}$ \\
\hline $\begin{array}{l}\text { Undried } \\
\text { brown rice }\end{array}$ & 30 & 96 & $15.9-32.0$ & 8 & 0.99 & 0.37 & 40 & $16.5-32.1$ & 0.97 & 0.50 & 0.06 \\
\hline $\begin{array}{l}\text { * Numb } \\
\dagger \text { Numb } \\
\ddagger \text { Coeffi } \\
\text { \& Standa } \\
\text { II Standa }\end{array}$ & of sam & 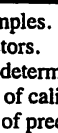 & $\begin{array}{l}\text { ation. } \\
\text { ation. } \\
\text { tion. }\end{array}$ & & & & & & & & \\
\hline
\end{tabular}






Figure 4-Correlation between reference moisture content of rough rice and estimated moisture content using a calibration model obtained from undried rough rice spectra with a light path length of $25 \mathrm{~mm}$.

of determination $\left(\mathrm{r}^{2}\right)$ of the validation set was greater than 0.9. The standard errors of prediction (SEP) for undried rough rice $(0.64$ and 0.70$)$ were higher than those for dried rough rice $(0.24$ and 0.28$)$, because high-moisture rough rice had a large moisture deviation. A scatter plot of reference vs estimated moisture content is shown in figure 4 . The calibration model was obtained from undried rough rice spectra with a light path length of $25 \mathrm{~mm}$. The values for $\mathrm{r}^{2}$, SEP, and bias were $0.96,0.70$, and -0.04 , respectively. These results indicated that NIRT spectroscopy could be used to determine the moisture content of undried whole-grain rough rice.

\section{Protein Content}

Calibration and validation statistics for brown rice protein content and milled rice protein content estimated from undried rough rice spectra, dried rough rice spectra and undried brown rice spectra are shown in tables 4 and 5 . The $r^{2}$ and SEP values of the undried rough rice validation sets showed that the accuracy of the models with a $25-\mathrm{mm}$ light path length $\left(r^{2}=0.70\right.$ and $S E P=0.24$ for brown rice, $r^{2}=0.76$ and SEP $=0.22$ for milled rice) was better than from models with a $20-\mathrm{mm}$ light path length $\left(\mathrm{r}^{2}=0.32\right.$ and $\mathrm{SEP}=0.33$ for brown rice, $\mathrm{r}^{2}=0.42$ and $\mathrm{SEP}=0.35$ for

Table 4. Calibration and validation statistics for brown rice protein content*

\begin{tabular}{|c|c|c|c|c|c|c|c|c|c|c|c|}
\hline \multirow{2}{*}{ Sample } & \multirow{2}{*}{$\begin{array}{c}\text { Light } \\
\text { Path } \\
\text { Length } \\
\text { (mm) }\end{array}$} & \multicolumn{5}{|c|}{ Calibration Model } & \multicolumn{5}{|c|}{ Validation } \\
\hline & & th $n$ & $\begin{array}{c}\text { Range } \\
(\%)\end{array}$ & $\mathrm{nF}$ & $\mathrm{r}^{2}$ & $\begin{array}{l}\text { SEC } \\
(\%)\end{array}$ & $\mathbf{n}$ & $\begin{array}{c}\text { Range } \\
(\%)\end{array}$ & $\mathbf{r}^{2}$ & $\begin{array}{l}\text { SEP } \\
(\%)\end{array}$ & $\begin{array}{l}\text { Bias } \\
(\%)\end{array}$ \\
\hline $\begin{array}{l}\text { Undried } \\
\text { rough rice }\end{array}$ & $\begin{array}{r}20 \\
e \quad 25 \\
\end{array}$ & $\begin{array}{r}70 \\
100 \\
\end{array}$ & $\begin{array}{l}7.4-9.4 \\
7.3-9.4 \\
\end{array}$ & $\begin{array}{r}5 \\
11 \\
\end{array}$ & $\begin{array}{l}0.46 \\
0.86 \\
\end{array}$ & $\begin{array}{l}0.30 \\
0.18 \\
\end{array}$ & $\begin{array}{l}35 \\
48 \\
\end{array}$ & $\begin{array}{l}7.5-9.2 \\
7.4-9.3 \\
\end{array}$ & $\begin{array}{l}0.32 \\
0.70 \\
\end{array}$ & $\begin{array}{l}0.33 \\
0.24 \\
\end{array}$ & $\begin{array}{l}0.02 \\
0.04\end{array}$ \\
\hline $\begin{array}{l}\text { Dried } \\
\text { rough rice }\end{array}$ & $\begin{array}{r}20 \\
e 25\end{array}$ & $\begin{array}{l}100 \\
100\end{array}$ & $\begin{array}{l}7.3-9.4 \\
7.3-9.4\end{array}$ & $\begin{array}{l}11 \\
10\end{array}$ & $\begin{array}{l}0.85 \\
0.87\end{array}$ & $\begin{array}{l}0.18 \\
0.17\end{array}$ & $\begin{array}{l}50 \\
50\end{array}$ & $\begin{array}{r}7.4-9.3 \\
7.4-9.3 \\
\end{array}$ & $\begin{array}{l}0.76 \\
0.71 \\
\end{array}$ & $\begin{array}{l}0.20 \\
0.25 \\
\end{array}$ & $\begin{array}{r}-0.02 \\
0.02 \\
\end{array}$ \\
\hline $\begin{array}{l}\text { Undried } \\
\text { brown rice }\end{array}$ & 30 & 100 & 7.3-9.4 & 7 & 0.74 & 0.23 & 48 & $7.4-9.3$ & 0.68 & 0.23 & 0.02 \\
\hline
\end{tabular}

Table 5. Calibration and validation statistics for milled rice protein content*

\begin{tabular}{|c|c|c|c|c|c|c|c|c|c|c|c|}
\hline \multirow{2}{*}{ Sample } & \multirow{2}{*}{$\begin{array}{c}\text { Light } \\
\text { Path } \\
\text { Length } \\
\text { (mm) }\end{array}$} & \multirow{2}{*}{ a) $n$} & \multicolumn{4}{|c|}{ Calibration Model } & \multicolumn{5}{|c|}{ Validation } \\
\hline & & & $\begin{array}{c}\text { Range } \\
(\%)\end{array}$ & $\mathrm{nF}$ & $\mathbf{r}^{2}$ & $\begin{array}{l}\text { SEC } \\
(\%)\end{array}$ & $\mathbf{n}$ & $\begin{array}{c}\text { Range } \\
(\%)\end{array}$ & $r^{2}$ & $\begin{array}{l}\text { SEP } \\
(\%)\end{array}$ & $\begin{array}{l}\text { Bias } \\
(\%)\end{array}$ \\
\hline $\begin{array}{l}\text { Undried } \\
\text { rough rice }\end{array}$ & $\begin{array}{r}20 \\
25\end{array}$ & $\begin{array}{r}70 \\
100\end{array}$ & $\begin{array}{l}6.9-8.9 \\
6.7-8.9\end{array}$ & $\begin{array}{r}9 \\
12\end{array}$ & $\begin{array}{l}0.81 \\
0.74\end{array}$ & $\begin{array}{l}0.20 \\
0.26\end{array}$ & $\begin{array}{l}36 \\
49\end{array}$ & $\begin{array}{l}6.9-8.7 \\
6.7-8.7\end{array}$ & $\begin{array}{l}0.42 \\
0.76\end{array}$ & $\begin{array}{l}0.35 \\
0.22\end{array}$ & $\begin{array}{l}-0.01 \\
-0.05\end{array}$ \\
\hline $\begin{array}{l}\text { Dried } \\
\text { rough rice }\end{array}$ & $\begin{array}{r}20 \\
\text { e } 25\end{array}$ & $\begin{array}{l}100 \\
100\end{array}$ & $\begin{array}{l}6.7-8.9 \\
6.7-8.9\end{array}$ & $\begin{array}{l}10 \\
12\end{array}$ & $\begin{array}{l}0.82 \\
0.89\end{array}$ & $\begin{array}{l}0.21 \\
0.17\end{array}$ & $\begin{array}{l}50 \\
50\end{array}$ & $\begin{array}{l}6.7-8.7 \\
6.7-8.7\end{array}$ & $\begin{array}{l}0.76 \\
0.80\end{array}$ & $\begin{array}{l}0.23 \\
0.21\end{array}$ & $\begin{array}{r}-0.01 \\
0.03\end{array}$ \\
\hline $\begin{array}{l}\text { Undried } \\
\text { brown rice }\end{array}$ & 30 & 99 & $6.7-8.9$ & 7 & 0.74 & 0.24 & 49 & $6.7-8.7$ & 0.71 & 0.25 & 0.02 \\
\hline
\end{tabular}

milled rice). Therefore, a light path length of $20 \mathrm{~mm}$ was too short to obtain sufficient information from rough rice.

Correlations between reference and estimated values of the protein content of brown rice and milled rice are shown in figures 5 and 6. Each calibration model was obtained from undried rough rice spectra with a light path length of $25 \mathrm{~mm}$. The $\mathrm{r}^{2}$ values of 0.70 and 0.76 and the SEP values of 0.24 and 0.22 were worse than those previously obtained from dried ground brown rice $\left(\mathrm{r}^{2}=0.98\right.$ and SEP $=0.15$, Suzuki et al., 1996), dried ground milled rice $\left(\mathrm{r}^{2}=0.94\right.$ and SEP $=0.17$, Natsuga et al., 1992), and dried wholegrain milled rice $\left(\mathrm{r}^{2}=0.97\right.$ and $\mathrm{SEP}=0.13$, Delwiche et al., 1996). In previous studies, the protein contents of brown rice and milled rice were estimated from their spectra, while the protein contents of brown rice and milled rice in this study were estimated from the undried rough rice spectra. The accuracy of the calibration models in this study, therefore, was lower than that in previous studies. Figures 5 and 6, however, show that NIRT technology had a reasonable ability to classify undried whole-grain rough rice into high and low protein content groups upon. arrival at a drying facility.

Shenk and Westerhaus (1993) reported the relationship between $\mathrm{r}^{2}$ and the percentage of times a sample is correctly classified, and they showed that about $84 \%$ of the samples would be correctly classified if undried rough rice

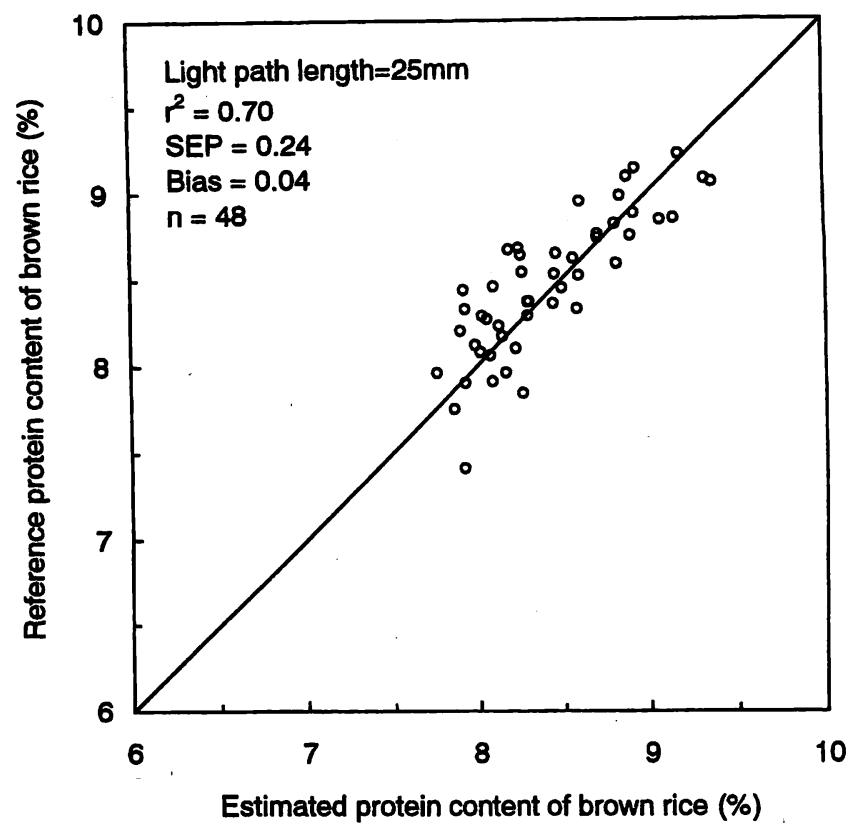

Figure 5-Correlation between reference protein content of brown rice and estimated protein content using a calibration model obtained from undried rough rice spectra with a light path length of $25 \mathbf{~ m m}$. 


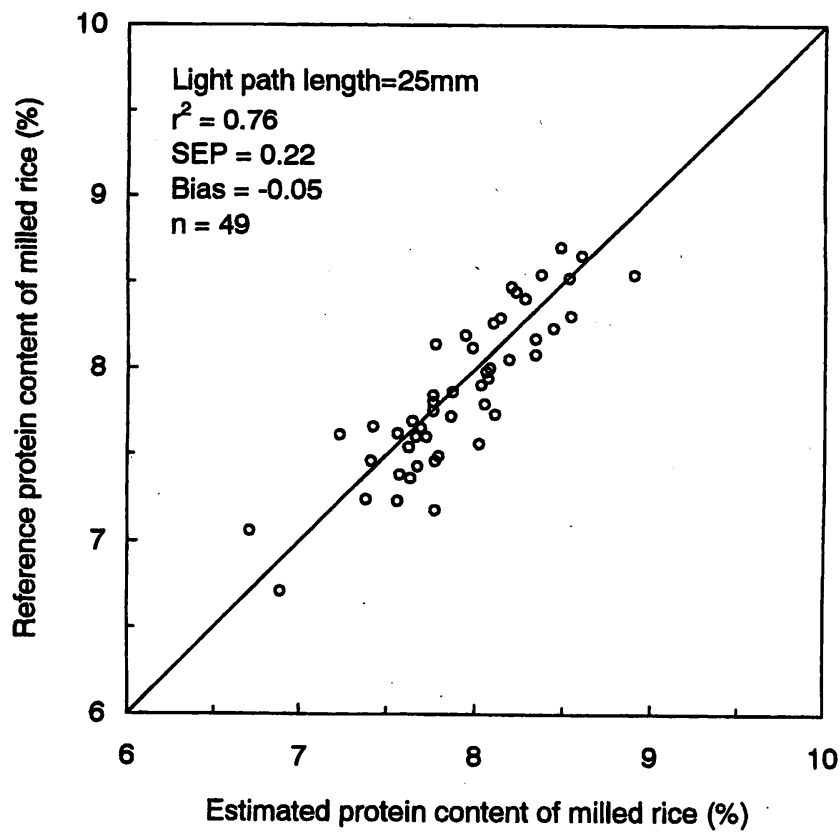

Figure 6-Correlation between reference protein content of milled rice and estimated protein content using a calibration model obtained from undried rough rice spectra with a light path length of $25 \mathbf{~ m m}$.

samples were divided into a high protein content group and a low protein content group by using the calibration model shown in figure $6\left(\mathrm{r}^{2}=0.76\right)$.

\section{Amylose Content}

Calibration and validation statistics for milled rice amylose content estimated from undried rough rice spectra, dried rough rice spectra and undried brown rice spectra are shown in table 6 . The results of validation with undried rough rice and a light path length of $25 \mathrm{~mm}$ are shown in figure $7\left(r^{2}=0.00\right.$ and SEP $\left.=0.27\right)$. Villareal et al. (1994) and Delwiche et al. $(1995,1996)$ reported that NIRT and NIRR could be used to determine the milled rice amylose content from the spectra of dried brown rice and dried milled rice. The samples in their studies consisted of widespread varieties of waxy rice, non-waxy short-grain rice, and non-waxy long-grain rice, and their rice samples contained a wide range of amylose contents (from $0 \%$ to $30 \%$ ). The low accuracy of the estimation obtained for milled rice amylose was thought to be due to the small range of amylose contents (from $20.6 \%$ to $21.9 \%$ ) in the samples and to the calibration models used for the estimation, which were obtained from undried rough rice spectra, dried rough rice spectra, and undried brown rice spectra.

Table 6. Calibration and validation statistics for milled rice amylose content*

\begin{tabular}{|c|c|c|c|c|c|c|c|c|c|c|c|}
\hline \multirow[b]{2}{*}{ Sample } & \multirow{2}{*}{$\begin{array}{l}\text { Light } \\
\text { Path } \\
\text { Length } \\
\text { (mm) }\end{array}$} & \multicolumn{5}{|c|}{ Calibration Model } & \multicolumn{5}{|c|}{ Validation } \\
\hline & & h & $\begin{array}{c}\text { Range } \\
(\%)\end{array}$ & $\mathrm{nF}$ & $\mathrm{r}^{2}$ & $\begin{array}{l}\text { SEC } \\
(\%)\end{array}$ & $\mathbf{n}$ & $\begin{array}{c}\text { Range } \\
(\%)\end{array}$ & $\mathbf{r}^{2}$ & $\begin{array}{l}\text { SEP } \\
(\%)\end{array}$ & $\begin{array}{l}\text { Bias } \\
(\%)\end{array}$ \\
\hline $\begin{array}{l}\text { Undried } \\
\text { rough rice }\end{array}$ & $\begin{array}{l}20 \\
25 \\
\end{array}$ & $\begin{array}{r}72 \\
100 \\
\end{array}$ & $\begin{array}{r}20.6-21.9 \\
20.6-21.9 \\
\end{array}$ & $\begin{array}{l}5 \\
9 \\
\end{array}$ & $\begin{array}{l}0.28 \\
0.37 \\
\end{array}$ & $\begin{array}{l}0.22 \\
0.21 \\
\end{array}$ & $\begin{array}{l}34 \\
50 \\
\end{array}$ & $\begin{array}{l}20.8-21.7 \\
20.8-21.8 \\
\end{array}$ & $\begin{array}{l}0.01 \\
0.00 \\
\end{array}$ & $\begin{array}{l}0.25 \\
0.27 \\
\end{array}$ & $\begin{array}{l}0.01 \\
0.05 \\
\end{array}$ \\
\hline $\begin{array}{l}\text { Dried } \\
\text { rough rice }\end{array}$ & $\begin{array}{l}20 \\
25 \\
\end{array}$ & $\begin{array}{l}100 \\
100\end{array}$ & $\begin{array}{l}20.6-21.8 \\
20.6-21.9 \\
\end{array}$ & $\begin{array}{l}7 \\
6 \\
\end{array}$ & $\begin{array}{l}0.40 \\
0.33 \\
\end{array}$ & $\begin{array}{l}0.20 \\
0.21 \\
\end{array}$ & $\begin{array}{l}50 \\
50 \\
\end{array}$ & $\begin{array}{l}20.8-21.9 \\
20.8-21.8 \\
\end{array}$ & $\begin{array}{l}0.21 \\
0.06\end{array}$ & $\begin{array}{l}0.23 \\
0.25\end{array}$ & $\begin{array}{r}-0.02 \\
0.02\end{array}$ \\
\hline $\begin{array}{l}\text { Undried } \\
\text { brown rice }\end{array}$ & e 30 & 100 & $20.6-21.9$ & 5 & 0.17 & 0.24 & 50 & $20.8-21.8$ & 0.07 & 0.22 & -0.06 \\
\hline
\end{tabular}

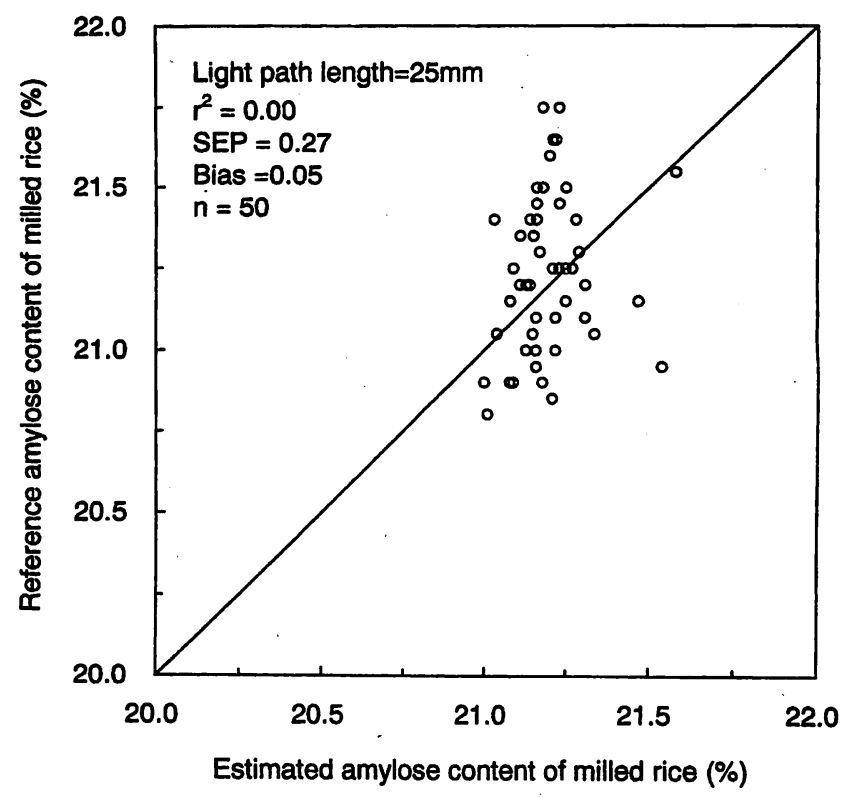

Figure 7-Correlation between reference amylose content of milled rice and estimated amylose content using a calibration model obtained from undried rough rice spectra with a light path length of $25 \mathrm{~mm}$.

\section{CONCLUSIONS}

NIRT spectroscopy could be used to the determine moisture content and protein content of undried wholegrain rough rice samples. Although slightly less accurate than NIR models based on dried ground milled rice, the NIRT undried whole-grain rough rice calibration model for estimating the protein content of brown rice and milled rice was sufficiently accurate for grading undried rough rice when it is transported to a drying facility from rice fields. This NIRT technology could be used to classify undried rough rice at drying facilities into qualitative groups such as high protein content rice and low protein content rice.

\section{REFERENCES}

Chen, H., B. P. Marks, and T. J. Siebenmorgen. 1997. Quantifying surface lipid content of milled rice via visible/near-infrared spectroscopy. Cereal Chem. 74(6): 826-831.

Delwiche, S. R., M. M. Bean, R. E. Miller, B. D. Webb, and P. C. Williams. 1995. Apparent amylose content of milled rice by near-infrared reflectance. Cereal Chem. 72(2): 182-187.

Delwiche, S. R., K. S. McKenzie, and B. D. Webb. 1996. Quality characteristics in rice by near-infrared reflectance analysis of whole-grain milled samples. Cereal Chem. 73(2): 257-263.

Inatsu, O. 1988. Studies on improving the eating quality of Hokkaido rice. Report of Hokkaido Prefectural Agricultural Experiment Stations, 66: 3-7. Hokkaido Central Agricultural Experiment Station, Naganuma, Japan.

Ishima, T., Hi. Taira, Ha. Taira, and K. Mikoshiba. 1974. Effect of nitrogenous fertilizer application and protein content in milled rice on olganoleptic quality of cooked rice. Report of National Food Research Institute, 29: 9-15. National Food Research Institute, Tsukuba, Japan.

Japan Food Agency. 1989. Japan Standard Methods for Assessing Physicochemical Properties of Agricultural Commodities, 2530. Tokyo, Japan: Ministry of Agriculture, Forestry and Fisheries. 
Kawamura, S., M. Natsuga, J. Himoto, and K. Itoh. 1991. Nearinfrared reflectance spectroscopy and sensory testing for taste evaluation of rice. J. Japanese Soc. Agric. Eng. 53(6): 93-96.

Kawamura, S., M. Natsuga, S. Kouno, and K. Itoh. 1996. Instrument analysis and sensory test for rice taste evaluation. $J$. Japanese Soc. Agric. Eng. 58(4): 95-100.

Kawamura, S., M. Natsuga, and K. Itoh. 1997. Visual and nearinfrared reflectance spectroscopy for rice taste evaluation. Transactions of the ASAE 40(6): 1755-1759.

Li, W. S., and J. T. Shaw. 1997. Determining the fat acidity of rough rice by near-infrared reflectance spectroscopy. Cereal Chem. 74(5): 556-560.

Natsuga, M., S. Kawamura, and K. Itoh. 1992. Precision and accuracy of near-infrared reflectance spectroscopy in determining constituent content of grain. J. Japanese Soc. Agric. Eng. 54(6): 89-94.

Osborne, B. G. 1995. NIR analysis of grain: Past, present and future. In Leaping Ahead with Near Infrared Spectroscopy, eds. G. D. Batten, P. C. Flinn, L. A. Welsh, and A. B. Blakeney, 133-135. Victoria, Australia: NIR Spectroscopy Group, Royal Australian Chemical Institute.

Shenk, J. S., and M. O. Westerhaus. 1993. Analysis of agriculture and food products by near-infrared reflectance spectroscopy. Part 1: 13-16. Port Matilda, Pa.: Infrasoft International Co.
Shibuya, N. 1990. Chemical structure of cell walls of rice grain and grain quality. Nippon Shokuhin Kogyo Gakkaishi 37(9): 740-748.

Suzuki, Y., S. Takahashi, M. Takebe, and K. Komae. 1996. Factors that affect protein contents in brown rice estimated by a nearinfrared spectrometer. Nippon Shokuhin Kogyo Gakkaishi 43(2): 203-210.

Villareal, C. P., N. M. Cruz, and B. O. Juliano. 1994. Rice amylose analysis by near-infrared transmittance spectroscopy. Cereal Chem. 71(3): 292-296.

Williams, V. R., W. T. Wu, H. Y. Tsai, and H. G. Bates. 1958. Varietal differences in amylose content of rice starch. J. Agric. \& Food Chem. 6: 47-48.

Windham, W. R., B. G. Lyon, E. T. Champagne, F. E. Barton, B. D. Webb, A. M. McClung, K. A. Moldenhauer, S. Linscombe, and K. S. McKenzie. 1997. Prediction of cooked rice texture quality using near-infrared reflectance analysis of whole-grain milled samples. Cereal Chem. 74(5): 626-632.

Yanase, H., K. Ohtsubo, K. Hashimoto, H. Sato, and T. Teranishi. 1984. Correlation between protein contents of brown rice and textural parameters of cooked rice and cooking quality of rice. Report of National Food Research Institute, 45: 118-122. National Food Research Institute, Tsukuba, Japan. 